\title{
Correction in supplement data
}

Cite as: Can Urol Assoc J 2016;10(9-10):E331. http://dx.doi.org/10.5489/cuaj.4155 Published online September 13, 2016

In the section entitled "Combination of radium-223 and docetaxel is well-tolerated, and improves time to prostatespecific antigen progression and progression-free survival in men with metastatic CRPC" on page S144 of the recently published "Prostate cancer update from the American Society of Clinical Oncology (ASCO) Annual Meeting 2016" sup- plement, ${ }^{1}$ the incorrect drug combination was stated. CUAJ regrets the error and apologizes for any inconvenience. Visit http://www.cuaj.ca/index.php/journal/article/view/4056/2814 for a corrected version of the data.

\section{Reference}

1. Kapoor A, Hotte SJ. Radionuclides. Can Urol Assoc J 2016;10 (7-8-Suppl3):S144-5. http://dx.doi.org/10.5489/cuaj.4056 